\title{
Fostering Problem Solving and Performance Assessment among Malaysian Mathematics Teachers
}

Madihah Khalid

Kulliyyah of Education, International Islamic University Malaysia, Jalan Gombak, Selangor

*Corresponding author: madihahkhalid@iium.edu.my

\begin{abstract}
Problem solving is considered important in the learning of mathematics because it develops the logical thinking aspect of doing mathematics. Thus it allows students to reason, communicate ideas, and employ knowledge to new and different variation of problems and situations. In the most recent Programme for International Student Assessment (PISA) result on problem-solving, Malaysian 15 year olds scored 422, which is significantly below the OECD average of 500. One of the causes for the unsatisfactory performance is that our students' ability to solve problems are not nurtured at the mainstream school. This paper will touch on some implication from the PISA result, the pedagogical approach of Malaysian mathematics teachers in teaching and learning of mathematics, and suggestions on how to implement lesson study to encourage teaching of mathematics through problem solving. At the same time, effective assessment of problem solving requires more than just looking at answers, it also involves a thorough analysis of the process. Therefore, in the evaluation process of problem solving in mathematics, the role of performance assessment will be examined - for example how it can be implemented together to satisfy the School-based assessment needs. Finally, results of a few research on problem solving and lesson study approach will be presented. The author's own research on lesson study, problem solving and performance assessment will be used as examples and discussed.
\end{abstract}

Keywords: Problem solving; mathematics lesson study; performance assessment; Malaysian Teacher's practice

(C) 2017 Penerbit UTM Press. All rights reserved

\subsection{INTRODUCTION}

This paper will start with the definitions of problem solving in mathematics education and why it is considered one of the most important skill in the 21 st century. The rest of this paper would recount the results of 15 -year old Malaysian students in international assessment namely PISA 2012, which was below the international standard. The result indicates that the issue is on problem solving. There will be an examination of the teaching of mathematics in Malaysian schools and the possible reasons why the implemented and the assessed curriculum diverge from the original intended curriculum. The current Malaysian written curriculum suggests the elements of problem solving in teaching mathematics, but was hardly implemented. This article then continues with suggestions of teaching mathematics through problem solving as practiced by many PISA high achieving countries. It also suggests the adoption of "lesson study" as continuous professional development, as well as a tool for research for school teachers. These suggestions will provide exposure and experience to the school teachers on how to teach through problem solving confidently. "Performance assessment" is recommended as an alternative to assess students because teaching through problem solving emphasizes not just the finished product but more importantly, the process. This method of assessment is holistic and can be easily applied to enhance the assessment portfolio for the school to record. Finally, in the discussion section, the results of lesson study and research on performance assessment by the author will be shared and this will lead to the conclusion.

\subsection{PROBLEM SOLVING AND ITS IMPORTANCE}

Problem solving in mathematics education is defined as "engaging in a task for which the solution method is not known in advance" (NCTM, 2000 , p. 52). In the process of problem solving, students must utilize their knowledge in trying to find a solution to a problem, a process which would lead to new mathematical understandings. Other things that students could acquire by learning the method of problem solving in mathematics are, "ways of thinking, habits of persistence and curiosity, and confidence in unfamiliar situations that will serve them well outside the mathematics classroom" (NCTM, 2000, p. 52). Additionally, problem-solving is considered as one of the most important skill in the 21 st century that a student should possess because there are many advantages a good problem solver would enjoy in everyday life and in the workplace. Therefore, problem solving should be considered an integral part of mathematics learning and it shouldn't be viewed as exercises that students perform at the end of every topic from the school textbook.

Observe the nature of the workforce today, and it can be seen that machines are taking over the repetitive actions in a job task. One in ten person encounter more complex problems that require at least 30 minutes to solve which imply the demand for complex problem-solving skills in many highly skilled managerial, professional and technical occupations (OECD, 2014a). Because of the importance of problemsolving, Program for International Assessment (PISA), besides testing 15-year old students on mathematics, science and reading, focuses testing students on problem solving too. In 2003, students were given a series of paper-based exercises to test their problem solving skills. 
Creative problem solving was tested in 2012, and collaborative problem solving in 2015 (OECD, 2013). In 2012, PISA defines problem solving competency as "an individual's capacity to engage in cognitive processing to understand and resolve problem situations where a method of solution is not immediately obvious. It includes the willingness to engage with such situations in order to achieve one's potential as a constructive and reflective citizen" (OECD, 2013, p. 122).

\subsection{MALAYSIAN STUDENTS’ PERFORMANCE IN PISA 2012 PROBLEM SOLVING}

In the 2012 result, 15-year old Malaysian students scored 421 in Mathematics and 422 in problem solving with the OECD average being 511 and 500 respectively. Rank wise Malaysia are placed at 52 out of 65 for mathematics and 39 out of 44 in problem solving (OECD, 2014b). About half of our students were in level 1 and below in problem solving, which seem to imply that they lack one of the important skills needed in the 21 st century. Only about $1 \%$ were among the top performers who are able to solve the most complex problems at level 5 and 6 and the rest are concentrated at level 2 and some at level 3 (OECD, 2014c). It was also stated in the document that problem solving performance correlated very strongly with mathematics performance in Malaysia at 0.83 . This finding indicates a strong connection between mathematical ability and problem solving power. Among other findings that is interesting is a statement that vocational students in Malaysia, who had a more practical hands-on approach on learning, performed better than their counterparts in normal government school. The quote below stated this point besides also pointing out the interpretations of this result:

"In Malaysia, Shanghai-China and Turkey, more than one in eight students attend a vocational study programme, and these students show significantly better performance in problem solving, on average, than students with comparable performance in mathematics, reading and science but who are in general study programmes. This finding can be interpreted in two ways. On the one hand, the curriculum and teaching practices in these vocational programmes may equip students better for tackling complex, real-life problems in contexts that they do not usually encounter at school. On the other hand, better-than-expected performance in problem solving may be an indication that in these programmes, students' ability to solve problems is not nurtured within the core academic subjects."

(OECD, 2014c, p. 14)

PISA 2012 assessed four distinct processes of problem-solving. Each question was designed to measure one of the group of processes, i.e. exploring and understanding, representing and formulating, planning and executing and also monitoring and reflecting and Malaysian students' average as compared to OECD average are as follows:

Table 1 PISA results showing percentage of the Malaysia students' performance in problem solving, for different processes (average proportion of full-credit responses)

\begin{tabular}{lcllll}
\hline & & $\begin{array}{l}\text { Items assessing } \\
\text { the process of } \\
\text { "exploring and } \\
\text { understanding" } \\
(10 \text { items })\end{array}$ & $\begin{array}{l}\text { Items assessing } \\
\text { the process of } \\
\text { "representing } \\
\text { and formulating" } \\
(8 \text { items })\end{array}$ & $\begin{array}{l}\text { Items assessing } \\
\text { the process of } \\
\text { "planning and } \\
\text { executing" } \\
(17 \text { items })\end{array}$ & $\begin{array}{l}\text { Items assessing } \\
\text { the process of } \\
\text { "monitoring and } \\
\text { reflecting" } \\
(7 \text { items })\end{array}$ \\
\hline Malaysia & $28.4 \%$ & $30.1 \%$ & $27.9 \%$ & $29.3 \%$ & $24.5 \%$ \\
\hline OECD & $45.0 \%$ & $47.9 \%$ & $42.7 \%$ & $46.4 \%$ & $40.3 \%$ \\
\hline
\end{tabular}

As can be seen from above (see Table 1), Malaysian 15-year olds scored thirty percent or less in all domains of the assessed processes, much below the OECD average which could be attributed to limited exposure to problem solving at school for Malaysian students. Students were exposed to mostly routine problems at school. At 15 years of age, tests and examinations that they encountered were mostly multiple choice questions (Lim \& Hwa, 2007; Lim, 2010). It is therefore not surprising that among the Malaysian students, there "is a pattern of relatively strong performance on selected-response items (and weak performance on constructed-response items” (OECD, 2014c, pg. 89). This fact reflects how mathematics is taught and tested at many schools in Malaysia.

\subsection{TEACHING OF MATHEMATICS IN MALAYSIAN SCHOOLS}

\section{Research Design}

Mullis et al. (2004) states that the activities in a mathematics lessons are predominantly made of direct instructions such as lecture, teacherguided student practice and students working on problems on their own. Mullis talked about this particular situation in the United States, but the same condition holds true in Malaysia to some extent. Other routine activities were reviewing homework, re-teaching and clarifying content, and also taking tests and quizzes. Mathematics teaching in many schools in Malaysia can still be characterized as teacher-centred (Lim, 2010). This is contrary to the recommendation by the Ministry of Education which suggest the focus of five elements in teaching and learning mathematics as listed below:

i) Problem solving in mathematics;

ii) Communication in mathematics;

iii) Reasoning in mathematics;

iv) Mathematical connections; and

v) Application of technology

(Ministry of Education Malaysia, 2003) In order to achieve the noble aims, the document further proposed a variety of other teaching approaches such as cooperative learning, 
contextual learning, mastery learning, constructivism, enquiry/discovery learning etc. Although the recommendation was put forward in 2003, we can still see in 2015, many teachers employing their normal teaching practices or strategies and students are still learning in the way that doesn't mirror the recommendations given by the Ministry. So, what can be done to resolve this?

In my humble opinion, one of the main reasons that triggers the problem is the over-emphasis of public standardized examination which has resulted in the teachers to quickly complete the syllabus to give students adequate time to revise for their tests/exams. Teachers use the "chalk-and-talk" method and spend a lot of time drilling the students with practice exercises and past examination questions. This way of teaching is triggered by high stakes examination that students in Malaysian public schools would go through (at least three for a normal student). Only until a few years ago, most of the public examination questions did not require higher-order thinking skills but rather, rote memorization and procedural skills. The ministry of education realizes this and has begun to solve this problem gradually. In fact the ministry had started the initiatives to improve the situation with the introduction of school-based assessment (SBA), which started with a number of glitches and setbacks in 2011 (Malaysian Examination Board, 2011). Unfortunately, teachers were not very clear of the goals and objectives of SBA in the beginning, and they felt burdened by the documentation that was required from them, especially entering the students mark online into a server that repeatedly crashed. Now the complaints have subsided after SBA was put on hold for a number of months and relaunched around the middle of 2014, where the online entry is no longer required. In 2014, the lower secondary assessment (PMR) was replaced with the Form 3 assessment (PT3) and the primary school assessment (UPSR) will be replaced in 2016 by a more balanced and holistic assessment.

The new assessments are made up of four components - central assessment, school assessment, psychometric assessment and the assessment of physical, sports and co-curricular activities. As a result, central assessments and school assessments can now be made to comprise of problem-solving questions. It would now be possible to have computer-based assessment on problem solving, similar to the creative problem solving established by PISA in 2012. As part of the mark from school assessment, teachers may apply alternative assessments such as performance-based assessment that assess students' performance of tasks or activities related to problem solving. This reform in assessment would eventually change teachers' ways of teaching, more towards a problem-solving approach. The problem-solving approach is also known as "teaching through problem solving" in many countries.

\subsection{TEACHING THROUGH PROBLEM SOLVING AND LESSON STUDY}

Teaching mathematics through problem solving is a term used to describe the method of teaching where the teaching of mathematics topics is focused through problem-solving contexts and enquiry-oriented environments. This method of teaching is demonstrated by the teacher "helping students to construct a deep understanding of mathematical ideas and processes by engaging them in doing mathematics: creating, conjecturing, exploring, testing, and verifying" (Lester et al., 1994, p.154). Lesh and Zawojewski (2007, p. 782) clarified that learning of mathematics should be organized through problem-solving, and proposed a shift from traditional views of problem solving to one that emphasizes, "synergistic relationships" between learning and problem solving which also involve "the process of interpreting a situation mathematically, which usually involves several iterative cycles of expressing, testing and revising mathematical interpretations - and sorting out, integrating, modifying, revising and or refining clusters of mathematical concepts from various topics within and beyond mathematics."

However, for a long time, the situation in classrooms consist of students solving routine textbook problems lacking real-world practice. Teachers are so accustomed to teaching the traditional way as some of them could not envision how mathematics can be taught through problem solving and even if they had seen the technique, were not confident enough to try it in their own class. This lack of exposure and experience in teaching through problem solving may be solved through lesson study.

Lesson Study (or jugyō kenkyū in Japanese) is a teaching improvement that can be considered as a professional development practice. It is claimed that teachers in Japan improve their teaching through "lesson study," where teachers collaboratively plan, observe, analyze, and refine actual classroom lessons, with the help of knowledgeable others (Murata \& Takahashi, 2002; Fernandez \& Yoshida, 2012). Japanese students have scored consistently well in international mathematics assessments such as PISA and the Trend in Mathematics and Science Study (TIMSS) ever since they were introduced. The PISA 2012 result saw 15-year old Japanese students scoring 552, ranked third and well above the 500 OECD average (OECD, 2014c). Currently, lesson study has gained positive reputation and is now being practiced all over the world.

Malaysian involvement in lesson study started as research collaboration with Australia around the year 2003 (Department of Education and Training, 2003) and research at Master or PhD level in 2004 (Lim \& Chew, 2005). Besides personal programmes initiated by particular lecturers, training of teachers at Seameo-Recsam was initiated in 2011, and later programmes with partner schools were conducted (Cheah \& Lim, 2010). Another lesson-study programme in Malaysia is conducted by the Professional Learning Community (PLC) involving 289 (15 primary and 274 secondary schools) schools. These programmes were spearheaded by the Teacher Education Section, Ministry of Education.

"Problem Solving Approach" was identified as the "Japanese teaching approach" when a group of researchers from TIMSS made a comparison between the teachings of a few countries involved in the study (Stigler \& Hiebert; 1999). It is considered a theory of teaching for the subject of Mathematics in inculcating self-learning for Japanese school children (Isoda, 2010) which include learning how to learn. Isoda (2010) also mentioned that another important product as a result of lesson study is a theory for designing curriculum which are described in teachers' guidebooks. These guidebooks will then be used by teachers and mathematics educators in sharing pedagogical content knowledge. The Japanese also claimed that they have been practicing lesson study for more than 130 years and contributed this practice as one of the main reasons for the adoption of problem-solving approach or teaching via problem solving.

Besides Japan, many countries have employed lesson study for teaching through problem solving both as a tool for research and also for continuous professional development. Teachers implementing lesson study would design and redesign their lessons to come up with activities/tasks/problems to accommodate problem solving. Since the developments of students' problem solving skills is important, there is a need to assess the process and product of problem solving. In the teaching and learning mathematics that focuses on problem solving approach, performance assessment can be used to aid in the instructions. Performance-based assessment may thus be promoted as a tool to assess the process and product of problem solving among students. 


\subsection{THE ROLE OF PERFORMANCE ASSESSMENT}

With the increased emphasis of problem solving in mathematics classes, the need for evaluation of progress and instruction in problem solving becomes more pressing. Some research dealing with the evaluation of problem solving involves diagnosing students' cognitive processes by evaluating the way an individual would undertake a problem-solving activity. Campione, Brown, and Connell (1988) term this method of evaluation as dynamic assessment. When students are given mathematics problems to solve, either individually or in groups, the teacher would then examine every necessary step of the process that the students take to solve problems. The finished product and the necessary interaction between student to teacher or student to student are also examined throughout their problem-solving activity. The amount and type of help needed by the students can provide good insight into the students' problem-solving abilities as well as their ability to learn and apply new principles.

Performance assessment, or alternative or authentic assessment as known to some, is a form of assessment that involves students performing a task rather than sitting for the traditional written test. It is formative rather than summative in nature. Most performance assessments require students to solve a problem or make an analysis. Rich performance assessments reveal a variety of problem solving approaches, thus providing insight into students' level of conceptual understanding. According to Chun (2010) the characteristics of a quality performance task are:

- Real-world scenario tasks, where students may assume roles in real-world scenarios.

- Authentic and complex process tasks where the scenarios reflect complex and ambiguity of the real-world challenges.

- Higher-order thinking tasks that require critical thinking, analytic reasoning, and problem solving.

- Authentic performance tasks where the 'product' reflects what a professional would produce.

- Tasks with transparent evaluation criteria where the learning outcomes drive the creation of the task.

Implementing a performance assessment in class is like killing two birds with one stone. A good performance task might take a lot of time to prepare but teaching, learning and assessment happens all at once in a more contextual manner. Instead of marking examination papers, teachers observe students doing a task and allocating marks on the process and product of the task using a rubric. Other domains of learning such as the affective and psychomotor domain, which is difficult to assess through a written test, can be satisfactorily assessed. Even the students' soft skills could be assessed all at once in performance assessment.

The author emphasized the practice of performance assessment in her role as teacher educator by making sure that teachers and studentteachers apply it in the classroom. Through school-based research, teachers and student-teachers are ensured to experience the technique of executing the performance-assessment approach. In a study by Khalid and Harun (2012), where performance assessment is used to assess and develop students' understanding of probability, they found that incorporating performance-based assessment in teaching on a regular basis will enhance students' 21 st century skills such as problem-solving, thinking, reasoning, explaining, collaborating, communicating and teamwork. Students in this study eventually became accustomed to this kind of assessment and in the end could see the relevance of the tasks and activities given to them. They began to see mathematics as something relevant and fun. Therefore practicing performance assessment can be combined with teaching through problem solving, to create a meaningful relevant class that make students better problem-solvers.

\subsection{DISCUSSION AND CONCLUSION}

This paper has tried to put together the possible reasons for the low performance of 15-year old Malaysian students according to the data obtained from PISA, and the possible solutions to the unsatisfactory result in problem solving particularly. The high-stakes examination and the traditional teaching style such as direct-instrcution are some of the possible reasons. The author recommended teaching and learning of mathematics through problem solving and performance assessment as addressing this phenomenon. The problem solving approach would allow students to develop concepts in contexts (Takahashi, 2010) that would allow them to make sense of mathematics. The adoption of lesson study is recommended both as CPD and tool for research as it enables teachers to learn through planning, doing and reflecting rather than reading, listening and seeing. Lesson study is now being used in many other countries such as Singapore, Hong Kong, China, the US, The UK, Sweden, Canada (Dudley, 2011). Top performing countries such as Singapore is known to practice teaching through problemsolving and Korea develop problem-solving skills in their students first before teaching mathematics skills (OECD, 2014c).

The performance assessment could address the alternative way of assessing students and add to the repertoire of teacher's assessment tools. Moreover, it could assess the many processes involved in problem solving and helps to justify ways of doing things. The author has taught assessments for mathematics education for years and found that teachers could learn to design proper activities or tasks that can be turned to good problem-solving classes and assess it at the same time. The author had also supervised several student-teachers who employed lesson study research when completing their dissertation and many professional development courses realized to train teachers on how to teach mathematics through problem solving (Khalid, 2015). Some of the research use lesson study to improve the design of instructions, some to examine teacher's perception of lesson study and some to look at teachers' and students' collaboration. The latest research conducted was about inculcating the awareness of Tsunami, which incorporated the teaching of the topic on "rate" so that lives can be saved from the tsunami (Khalid, 2014; Khalid \& Dk. Haslinah, 2014). Among the common findings from the research that had been undertaken were: Lesson Study promotes the practice of innovative teaching; Lesson Study provides teachers with a platform to improve and reflect their own teaching; Lesson Study has many advantages compared to other professional development programmes (Suhaili \& Madihah, 2011; Suhaili, Shahrill \& Khalid, 2014).

From the results of the research conducted with several students and from the CPD courses attended by teachers from various school levels, the author has the confidence that teachers can be encouraged to improve their practice of teaching to the problem solving approach in making mathematics teaching more meaningful. As a result, teachers who practice this teaching technique would in turn, enhance the problem solving ability of their students. 


\section{References}

Campione, J. C., Brown, A. L., \& Connell, M. L. (1988). Metacognition: On The Importance Of Understanding What You Are Doing. In R. I. Charles \& E. A. Silver (Eds.), Research Agenda For Mathematics Education: The Teaching And Assessing Of Mathematical Problem Solving, 93-114. Hillsdale, NJ: Lawrence Erlbaum.

Cheah, UH \& Lim, C. S. (2010). Disseminating and Popularising Lesson Study in Malaysia and Southeast Asia. Paper presented at the APEID Hiroshima Seminar "Current Status and Issues on Lesson Study in Asia and the Pacific Regions" held at Hiroshima University in Japan from 18th to 21st January 2010

Chun, M (2010). Taking Teaching to (Performance) Task: Linking Pedagogical and Assessment Practices Change: The4Magazine of Higher Learning, 42(2), 22-29.

Department of Education and Training. (2003). Lesson Study Project: Evaluation Report. Ryde, New South Wales: Department of Training professional support and Curriculum Directorate.

Dudley, P. (2011). Lesson Study: What Is It, How And Why It Works And Who Is Using It. www.teaching expertise.com

Fernandez, C., \& Yoshida, M. (2012). Lesson study: A Japanese Approach To Improving Mathematics Teaching And Learning. Routledge.

Isoda, M (2010). Lesson Study: Problem Solving Approaches in Mathematics Education as a Japanese Experience. International Conference on Mathematics Education Research 2010 (ICMER 2010). Procedia Social and Behavioral Sciences 8 (2010) 17-27

Lesh, R., Zawojewski, J. (2007) Problem Solving and Modeling. In F. Lester (Ed.), Handbook for Research on Mathematics Education (2nd ed), p. 763-804. Charlotte, C: Information Age Publishing

Lester, F.K.Jr., Masingila, J.O., Mau, S.T., Lambdin, D.V., dos Santon, V.M. and Raymond, A.M. (1994). 'Learning how to teach via problem solving'. in Aichele, D. and Coxford, A. (Eds.) Professional Development for Teachers of Mathematics, 152-166. Reston, Virginia: NCTM.

Lim, C. S, White, A., \& Chiew, C. M. (2005). Promoting Mathematics Teacher Collaboration through Lesson Study: What Can We Learn from Two Countries Experience? In A. Rogerson (Ed.), Proceedings of the 8th International Conference of the Mathematics Education into the 21st Century Project: "Reform, Revolution and Paradigm Shifts in Mathematics Education", 135-13.

Lim, C. S., \& Hwa, T. Y. (2006). Promoting Mathematical Thinking In The Malaysian Classroom: Issues And Challenges. Paper Presented At The Meeting of the APEC-Tsukuba International Conference, Japan.

Lim, C. S. (2010). Assessment in Malaysian School Mathematics: Issues and Concerns. Paper Presented At The Meeting of the APEC-Tsukuba International Conference, Japan.

Khalid, M (in press). Reminiscing The Lesson Study Journey In Brunei. Lesson Study Seminar Book. Brunei Darussalam: UBD

Khalid, Madihah (2014) Innovation In Education Through Lesson Study: Incorporating Disaster Risk Reduction In Mathematics Lesson To Inculcate Tsunami Awareness. In: International Research, Invention and Innovation Exhibition 2014 (IRIIE2014), 11th -13th June 2014, Gombak, Kuala Lumpur.

15. Khalid, M \& Dk. Haslinah (2014). Realization of Future Trends: Improving Students' Collaborative Problem Solving via Lesson Study Paper presented at the Malaysian Education Deans Council (MEDC), 25-26 Sept., 2014, University Malaya,

Khalid, M \& Harun, Z. (2012). Using Performance Assessment To Assess And Develop Understanding Of Probability. Paper presented at the 12 th International Congress on Mathematical Education Program 8 - 15 July, 2012, COEX, Seoul, Korea

Malaysian Examination Board (2011). Pengendalian Ujian Lisan Berasaskan Sekolah (ULBS). Kuala Lumpur: Kementerian Pelajaran Malaysia.

Mullis,V.S, Martin M.O., Gonzalez, E.J \& Chrostowski, S. J. (2004). TIMSS 2003 International Mathematics Report. TIMSS \& PIRLS International Study Center, Lynch School of Education: Boston College.

Murata, A., \& Takahashi, A. (2002). District-level lesson study: How Japanese Teachers Improve Their Teaching Of Elementary Mathematics. In Research Precession of National Council of Teachers of Mathematics Annual Meeting, Las Vegas, NV.

OECD (2013). PISA 2012 Assessment and Analytical Framework: Mathematics, Reading, science, Problem solving and Financial literacy OECD Publishing. http://dx.doi.org/10.1787/9789264190511-en

OECD (2014a), Education at a Glance 2014: Highlights, OECD Publishing, Paris. DOI: http://dx.doi.org/10.1787/eag highlights-2014-en

OECD (2014b). PISA 2012 Results in Focus What 15-year-Olds Know And What They Can Do With What They Know.

OECD (2014c). PISA 2012 Creative Problem Solving: Students' Skills In Tackling Real-Life Problems (Vol. 5). PISA. OECD publishing. DOI: http://dx.doi.org/ $10.1787 / 9789264208070$-en

Suhaili, A. S. \& Khalid, M (2011). Mathematics Teachers' Perception of Lesson Study as a Continuous Professional Development Programme. Journal of Science and Mathematics Education in Southeast Asia, 34, 67-89.

Suhaili, Ade Shahren and Shahrill, Masitah and Khalid, Madihah (2014) The Impact Of Lesson Study On Primary Mathematics Teachers' Instructions in Brunei Darussalam. In: International Conference on Education in Mathematics, Science and Technology (ICEMST2014), 16th-18th May 2014, Konya, Turkey

Takahashi, A., Lewis, L, Perry, R. (2013). "A US Lesson Study Network To Spread Teaching Through Problem Solving", International Journal for Lesson and Learning Studies, 2(3), 237 - 255 